\title{
Effect of the Multiple Intravenous Administration of Cultured Human Autologous Adipose-Derived Stem Cells on Tumor Biomarker Levels
}

\author{
Jeong-Chan Ra*, Yun-Joung Kim and Eun-Young Kim
}

BIOSTAR Stem Cell Research Institute, Republic of Korea

\begin{abstract}
Many studies have been conducted to cultivate and utilize patients' own adipose-derived stem cells for the treatment of various incurable diseases and for regenerative medicine that can prolong lifespan. Despite the significant achievements made thus far, the lack of confidence with regard to safety, particularly the concern about tumorigenicity, has made researchers hesitant to actively apply cultured human autologous adipose-derived cells in clinical trials. Therefore, studies on the tumorigenicity of cultured adipose-derived stem cells are very important for expanding the field of stem cell-utilizing regenerative medicine. It is also important to study their effect on tumor biomarker levels. Long-term follow-up studies of tumorigenicity after multiple intravenous administrations of cultured human autologous adipose-derived stem cells have not been reported worldwide. Therefore, the authors have examined 462 Koreans who were administered more than 1 billion cultured autologous adipose-derived stem cells multiple times from 2010 to 2013 at medical institutions in Japan. We then conducted the first retrospective research in the world on the changes in eight types of tumor biomarkers over three-six years. According to the results of our analysis, there were no significant changes in the observed tumor biomarkers, irrespective of gender and age. These results suggest that multiple administrations of autologous adipose-derived stem cells cultured in accordance with the authors' method do not affect tumorigenicity.
\end{abstract}

Keywords: Adipose-derived stem cells; Multiple intravenous infusion; Tumor biomarker test; Tumorigenicity

\section{Introduction}

Human adipose stem cells are being actively researched as a material for regenerative medicine for their ability to treat irreversible diseases such as dementia, Parkinson's disease, spinal cord injuries, degenerative arthritis, and provide skin care. Through non-clinical and clinical studies on Buerger's disease, Perry-Romberg disease [1], and critical limb ischemia [2], the authors have already confirmed the revascularization of adipose stem cells and the possibility of treatment via anti-inflammatory reactions. We have also presented clinical results for degenerative arthritis [3]. In addition, we have completed a safety study for the treatment of spinal cord injuries [4] by administering cultured autologous adipose stem cells intravenously and reported the possibility of treating autoimmune diseases [5,6]. Anti-aging and life extension studies [7] via multiple administrations of adipose stem cells.

In recent years, the FDA (IND 17201) has approved our clinical trial plan to confirm the safety and efficacy of using autologous adipose stem cells in patients with Alzheimer's disease [6] via 10 times of intravenous administrations.

However, although these positive effects were revealed, safety concerns regarding cultured autologous adipose stem cells still make people hesitant about their clinical use. In particular, it has to be considered seriously that concerns about the possibility of cancer development derived from cultured autologous adipose stem cells. The reasons for concerns about the possibility of cancer promotion by the administration of cultured adipose stem cells [8,9] are as follows: (1) genetic mutations may occur during the culturing process and (2) the growth factors secreted by stem cells may promote the growth of cancer cells and create a favorable environment for them. However, several reports have presented that stem cells inhibit cancer development [10$12]$, which suggests the importance of discerning the characteristics of cultured stem cells.

There have been contradictory research results that adipose stem cells can proliferate and inhibit cancer; however, there has been no longterm follow-up study on Tumorigenicity after multiple administrations of cultured human autologous adipose stem cells. Therefore, the authors conducted a world-first retrospective study of the changes in eight types of tumor biomarker over three-six years in approximately about 500 Koreans who were intravenously administered more than 1 billion cells multiple times at medical institutions in Japan from 2010 to 2013.

\section{Materials and Methods}

\section{Isolation and culture of hAdMSCs}

The method and medium used for culturing autologous adipose stem cells were the same as that described in the authors' safety report in Stem Cell and Development in 2012 [4].

Human adipose tissues were obtained by simple liposuction from the abdominal subcutaneous fats with an informed consent. Subcutaneous adipose tissues were digested with collagenase I $(1 \mathrm{mg} / \mathrm{ml})$ under gentle agitation for $60 \mathrm{~min}$ at $37^{\circ} \mathrm{C}$. The digested tissues were filtered through a $100 \mathrm{mM}$ nylon sieve to remove cellular debris and were centrifuged at $470 \mathrm{~g}$ for $5 \mathrm{~min}$ to obtain a pellet. The pellet was resuspended in Dulbecco's modified Eagle's medium (DMEM; Invitrogen)-based media containing $0.2 \mathrm{mM}$ ascorbic acid and $10 \%$ fetal bovine serum (FBS) obtained from bovine spongiform encephalopathy free herd. The cell suspension was recentrifuged at $470 \mathrm{~g}$ for $5 \mathrm{~min}$. The supernatant was discarded, and the cell pellet was collected. The cell fraction was cultured overnight at $37^{\circ} \mathrm{C} / 5 \% \mathrm{CO}_{2}$ in DMEM-based media containing $0.2 \mathrm{mM}$ ascorbic acid and 10\% FBS. After $24 \mathrm{~h}$, the cell adhesion was checked

*Corresponding author: Jeong-Chan Ra, BIOSTAR Stem Cell Research Institute, Republic of Korea, Tel: +82-2-070-4665-1174; Fax: +82-2-858-8140; E-mail: jcra@stemcellbio.com

Received August 28, 2017; Accepted November 15, 2017; Published November 20, 2017

Citation: Ra J, Kim Y, Kim E (2017) Effect of the Multiple Intravenous Administration of Cultured Human Autologous Adipose-Derived Stem Cells on Tumor Biomarker Levels. J Clin Case Rep 7: 1040. doi: 10.4172/2165-7920.10001040

Copyright: (c) $2017 \mathrm{Ra} \mathrm{J}$, et al. This is an open-access article distributed under the terms of the Creative Commons Attribution License, which permits unrestricted use, distribution, and reproduction in any medium, provided the original author and source are credited. 
under an inverted microscope, and nonadherent cells were removed by washing with phosphate-buffered saline (PBS). The cell medium was changed to Keratinocyte-SFM (Invitrogen)-based media containing 0.2 $\mathrm{mM}$ ascorbic acid, $0.09 \mathrm{mM}$ calcium, $5 \mathrm{ng} / \mathrm{ml} \mathrm{rEGF}$, and 5\% FBS. The cells were maintained for 4-5 days until confluent (passage 0 ). When the cells reached $90 \%$ confluency, they were subculture-expanded in Keratinocyte-SFM-based media containing $0.2 \mathrm{mM}$ ascorbic acid, $0.09 \mathrm{mM}$ calcium, $5 \mathrm{ng} / \mathrm{ml} \mathrm{rEGF}$, and $5 \%$ FBS until passage 3 or 4 . FBS contaminant from cultured MSCs were completely removed by several washing with PBS and was verified through the test of albumin level below the measurement limit using a bovine albumin ELISA quantitiation kit (Bethyl Laboratories). The Korea Food and Drug Administration permitted the FBS-eliminated MSCs for clinical study. Aliquots of the hAdMSCs (human adipose derived mesenchymal stem cells) are then tested for cell viability and fungal, bacterial, endotoxin, and mycoplasma contamination as demanded by the Code of Federal Regulations, Title 21 (21CFR) before further use. The details of specific standards are found in the 21CFR, Sections 610. The procedure for hAdMSCs preparation was performed under GMP conditions in the Stem Cell Research Center of RBIO.

\section{Subjects and patients}

The subjects were administered more than 1 billion cells of autologous adipose-derived mesenchymal stem cells for three years from January 2010 to December 31, 2013. We received IRB approval for the use of human biological material (The Institutional Review Board (IRB) at the BIOSTAR Stem Cell Research Institute. Ltd., Seoul, Korea (RBIO 2016-03-001), and donors consented to their biological material being used for research with their health checkup common questionnaire and cancer screening questionnaire.

The tumor biomarker test in their blood was conducted both before and after the administration of cells from May 2016. The age ranges of the subjects were as follows: male $69.34 \pm 9.09$ (41-87) and female $67.24 \pm 9.13$ (36-87). There were 202 male and 260 female subjects, and the number of administered cells were $2.743( \pm 1.397)$ billion for males and $2.525( \pm 1.274)$ billion for females. Each administration contained 100-300 million cells that were suspended in $100 \mathrm{ml}$ of sterile sodium chloride injection per 100 million cells and then injected intravenously. The survey results showed that 33 out of the 202 men and 26 out of the 260 women had a history of cancer, while 10 males and 11 females were infected with hepatitis viruses ( $\mathrm{B}$ or $\mathrm{C}$ ). The information of participants (Tables 1- 3).

\section{Method for collecting and storing tumor biomarker diagnostic samples}

Prior to stem cell administration, the blood serum was separated from the blood that had been stored before initially collecting adipose cells $(2010-2013)$ and then stored at $-25^{\circ} \mathrm{C}$ or colder. After the administration of cells, blood was collected from May 2016 to July 2017 through hospital and paramedic visits. Therefore, the interval between the collection of blood samples before and after administration varied from person to person; however, it was generally three to six years.

\section{Test items and methods}

In terms of test items, alpha-fetoprotein (AFP), carcinoembryonic antigen (CEA), cancer antigen 19-9 (CA19-9), Cancer antigen 72-4 (CA72-4), total prostate specific antigen (T-PSA), and free/totalprostate specific antigen (F/T-PSA) ratio were selected for males, while Alpha-fetoprotein (AFP), Carcinoembryonic antigen (CEA), Cancer antigen 19-9 (CA19-9), Cancer antigen 72-4 (CA72-4), Carcinoma

\begin{tabular}{|c|c|c|c|}
\hline \multirow{2}{*}{ Tumor biomarkers } & \multirow{2}{*}{$\begin{array}{c}\text { Pre/Post IV } \\
\text { administration }\end{array}$} & \multicolumn{2}{|c|}{ Total } \\
\hline & & $\mathbf{N}$ & Mean \pm SD \\
\hline \multirow{4}{*}{ AFP } & Before & 462 & $3.653 \pm 5.241$ \\
\hline & After & 462 & $3.679 \pm 1.955$ \\
\hline & $\begin{array}{l}\text { Variation }^{1)} \text { between pre/ } \\
\text { post IV }\end{array}$ & 462 & $-0.027 \pm 4.833$ \\
\hline & $\mathrm{p}$-value ${ }^{\S}$ & \multicolumn{2}{|c|}{$<0.0001$} \\
\hline \multirow{4}{*}{ CEA } & Before & 462 & $2.558 \pm 1.902$ \\
\hline & After & 462 & $2.986 \pm 2.480$ \\
\hline & $\begin{array}{l}\text { Variation }{ }^{1)} \text { between pre/ } \\
\text { post IV }\end{array}$ & 462 & $-0.427 \pm 1.125$ \\
\hline & $\mathrm{p}$-value $\$$ & \multicolumn{2}{|c|}{$<0.0001$} \\
\hline \multirow{4}{*}{ CA19-9 } & Before & 462 & $7.852 \pm 7.180$ \\
\hline & After & 462 & $\begin{array}{c}11.652 \pm \\
12.179\end{array}$ \\
\hline & $\begin{array}{c}\text { Variation }{ }^{1)} \text { between pre/ } \\
\text { post IV }\end{array}$ & 462 & $-3.800 \pm 8.654$ \\
\hline & p-value ${ }^{\S}$ & \multicolumn{2}{|c|}{$<0.0001$} \\
\hline \multirow{4}{*}{ CA72-4 } & Before & 462 & $4.003 \pm 20.600$ \\
\hline & After & 462 & $3.293 \pm 5.568$ \\
\hline & $\begin{array}{c}\text { Variation }^{1)} \text { between pre/ } \\
\text { post IV }\end{array}$ & 462 & $0.710 \pm 21.073$ \\
\hline & $\mathrm{p}$-value $\$$ & \multicolumn{2}{|c|}{$<0.0001$} \\
\hline \multirow{4}{*}{ T-PSA } & Before & 202 & $0.941 \pm 1.140$ \\
\hline & After & 202 & $1.442 \pm 1.711$ \\
\hline & $\begin{array}{l}\text { Variation }^{1)} \text { between pre/ } \\
\text { post IV }\end{array}$ & 202 & $-0.501 \pm 1.138$ \\
\hline & p-value $\$$ & \multicolumn{2}{|c|}{$<0.0001$} \\
\hline \multirow{4}{*}{ F/T-PSA } & Before & 202 & $\begin{array}{l}29.494 \pm \\
48.446\end{array}$ \\
\hline & After & 202 & $\begin{array}{l}36.112 \pm \\
28.242\end{array}$ \\
\hline & $\begin{array}{l}\text { Variation }^{1)} \text { between pre/ } \\
\text { post IV }\end{array}$ & 202 & $-6.618 \pm 43.097$ \\
\hline & p-value $\S$ & \multicolumn{2}{|c|}{$<0.0001$} \\
\hline \multirow{4}{*}{ CA15-3 } & Before & 260 & $9.145 \pm 3.762$ \\
\hline & After & 260 & $9.235 \pm 3.654$ \\
\hline & $\begin{array}{l}\text { Variation }{ }^{1)} \text { between pre/ } \\
\text { post IV }\end{array}$ & 260 & $-0.090 \pm 1.723$ \\
\hline & p-value $\$$ & \multicolumn{2}{|c|}{0.1378} \\
\hline \multirow{4}{*}{ CA125 } & Before & 260 & $12.284 \pm 8.979$ \\
\hline & After & 260 & $12.090 \pm 7.749$ \\
\hline & $\begin{array}{c}\text { Variation }^{1)} \text { between pre/ } \\
\text { post IV }\end{array}$ & 260 & $0.194 \pm 8.299$ \\
\hline & $p$-value ${ }^{\S}$ & \multicolumn{2}{|c|}{0.5601} \\
\hline
\end{tabular}

Variation $=$ Pre-treatment value - post-treatment value, $\S$, Wilcoxon Signed Rank Test result

AFP: Alpha-Fetoprotein, CEA: Carcino-Embryonic Antigen, CA19-9: Cancer Antigen 19-9, CA72-4: Cancer Antigen 72-4, T-PAS: Total-Prostate Specific Antigen, F/T-PAS: Free/Total- Prostate Specific Antigen, CA15-3: Carcinoma Antigen 15-3, CA125: Carcinoma Antigen 125.

Table 1: The mean value of the tumor biomarker before and after the intravenous administration of cultured of autologous adipose-derived stem cells.

antigen 15-3 (CA15-3), and cancer antigen 125 (CA125) were selected for females. The tumor biomarker diagnostic reagents were purchased from Roche Diagnostics (Each was as follows: elecsys AFP, elecsys CEA, elecsys CA19-9, elecsys CA72-4, elecsys CA15-3, and elecsys CA125.)

They were measured using a Cobas-e411 (Roche Diagnostics, Germany) automated analyzer based on the principle of electrochemiluminescence (ECL) immunoassay. The reference values were as follows: AFP $<7.0 \mathrm{ng} / \mathrm{ml}$, CEA $<4.7 \mathrm{ng} / \mathrm{ml}$, CA19-9 $<39.0 \mathrm{U} /$ $\mathrm{ml}$, CA72- $4<6.9 \mathrm{U} / \mathrm{ml}, \mathrm{T}-\mathrm{PSA}<4.0 \mathrm{ng} / \mathrm{ml}$, F/T-PSA ratio $>23 \%$, CA15$3<26.4 \mathrm{U} / \mathrm{ml}$, and CA125 $<35 \mathrm{U} / \mathrm{ml}$, which were provided by Roche 


\begin{tabular}{|c|c|c|c|c|c|c|c|}
\hline \multicolumn{8}{|c|}{$\begin{array}{l}\text { Rate of participants with a risk value for each tumor biomarker (\%) } \\
\text { (The number of participants having the risk value/the total number of participants) }\end{array}$} \\
\hline Tumor marker (Risk range) & IV Age & 80 & 70 & 60 & 50 & $30-40$ & Total \\
\hline \multirow{2}{*}{$\begin{array}{l}\text { AFP } \\
(>400 \mathrm{ng} / \mathrm{ml})\end{array}$} & Before & $0 \%(0 / 49)$ & $0 \%(0 / 203)$ & $0 \%(0 / 138)$ & $0 \%(0 / 56)$ & $0 \%(0 / 16)$ & $0 \%(0 / 462)$ \\
\hline & After & $0 \%(0 / 49)$ & $0 \%(0 / 203)$ & $0 \%(0 / 138)$ & $0 \%(0 / 56)$ & $0 \%(0 / 16)$ & $0 \%(0 / 462)$ \\
\hline \multirow{2}{*}{$\begin{array}{l}\text { CEA } \\
(>10 \mathrm{ng} / \mathrm{ml})\end{array}$} & Before & $0 \%(0 / 49)$ & $0.49 \%(1 / 203)$ & $1.44 \%(2 / 138)$ & $0 \%(0 / 56)$ & $0 \%(0 / 16)$ & $0.64 \%(3 / 462)$ \\
\hline & After & $0 \%(0 / 49)$ & $0.49 \%(1 / 203)$ & $0.72 \%(1 / 138)$ & $0 \%(0 / 56)$ & $0 \%(0 / 16)$ & $0.43 \%(2 / 462)$ \\
\hline \multirow{2}{*}{$\begin{array}{l}\text { CA19-9 } \\
(>500 \mathrm{U} / \mathrm{ml})\end{array}$} & Before & $0 \%(0 / 49)$ & $0 \%(0 / 203)$ & $0 \%(0 / 138)$ & $0 \%(0 / 56)$ & $0 \%(0 / 16)$ & $0 \%(0 / 462)$ \\
\hline & After & $0 \%(0 / 49)$ & $0 \%(0 / 203)$ & $0 \%(0 / 138)$ & $0 \%(0 / 56)$ & $0 \%(0 / 16)$ & $0 \%(0 / 462)$ \\
\hline \multirow{2}{*}{$\begin{array}{l}\text { CA72-4 } \\
(>100 \mathrm{U} / \mathrm{ml})\end{array}$} & Before & $0 \%(0 / 49)$ & $0.49 \%(1 / 203)$ & $0.72 \%(1 / 138)$ & $0 \%(0 / 56)$ & $0 \%(0 / 16)$ & $0.21 \%(1 / 462)$ \\
\hline & After & $0 \%(0 / 49)$ & $0 \%(0 / 203)$ & $0 \%(0 / 138)$ & $0 \%(0 / 56)$ & $0 \%(0 / 16)$ & $0 \%(0 / 462)$ \\
\hline \multirow{2}{*}{$\begin{array}{l}\text { T-PSA } \\
(>10 \mathrm{ng} / \mathrm{ml})\end{array}$} & Before & $0 \%(0 / 26)$ & $1 \%(1 / 93)$ & $0 \%(0 / 55)$ & $0 \%(0 / 21)$ & $0 \%(0 / 7)$ & $0.49 \%(1 / 202)$ \\
\hline & After & $0 \%(0 / 26)$ & $1 \%(1 / 93)$ & $1.81 \%(1 / 55)$ & $0 \%(0 / 21)$ & $0 \%(0 / 7)$ & $0.99 \%(2 / 202)$ \\
\hline \multirow{2}{*}{$\begin{array}{c}\text { F/T-PSA } \\
(<10 \%)\end{array}$} & Before & $0 \%(0 / 26)$ & $0 \%(0 / 93)$ & $1.81 \%(1 / 55)$ & $0 \%(0 / 21)$ & $0 \%(0 / 7)$ & $0.49 \%(1 / 202)$ \\
\hline & After & $0 \%(0 / 26)$ & $0 \%(0 / 93)$ & $1.81 \%(1 / 55)$ & $0 \%(0 / 21)$ & $0 \%(0 / 7)$ & $0.49 \%(1 / 202)$ \\
\hline \multirow{2}{*}{$\begin{array}{l}\text { CA15-3 } \\
(>30 \mathrm{U} / \mathrm{ml})\end{array}$} & Before & $0 \%(0 / 23)$ & $0 \%(0 / 110)$ & $0 \%(0 / 83)$ & $0 \%(0 / 35)$ & $0 \%(0 / 9)$ & $0 \%(0 / 260)$ \\
\hline & After & $0 \%(0 / 23)$ & $0 \%(0 / 110)$ & $0 \%(0 / 83)$ & $0 \%(0 / 35)$ & $0 \%(0 / 9)$ & $0 \%(0 / 260)$ \\
\hline \multirow{2}{*}{$\begin{array}{l}\mathrm{CA} 125 \\
(>60 \mathrm{U} / \mathrm{ml})\end{array}$} & Before & $0 \%(0 / 23)$ & $0 \%(0 / 110)$ & $0 \%(0 / 83)$ & $2.85 \%(1 / 35)$ & $0 \%(0 / 9)$ & $0.38 \%(1 / 260)$ \\
\hline & After & $0 \%(0 / 23)$ & $0 \%(0 / 110)$ & $0 \%(0 / 83)$ & $2.85 \%(1 / 35)$ & $0 \%(0 / 9)$ & $0.38 \%(1 / 260)$ \\
\hline
\end{tabular}

AFP: Alpha-Fetoprotein, CEA: Carcino-Embryonic Antigen, CA19-9: Cancer Antigen 19-9, CA72-4: Cancer Antigen 72-4, T-PAS: Total-Prostate Specific Antigen, F/T-PAS: Free/Total-Prostate Specific Antigen, CA15-3: Carcinoma Antigen 15-3, Ca125: Carcinoma Antigen 125.

Table 2: Age-specific distribution of participants who had risk levels for tumor biomarkers before and after the intravenous administration of cultured autologous adiposederived stem cells.

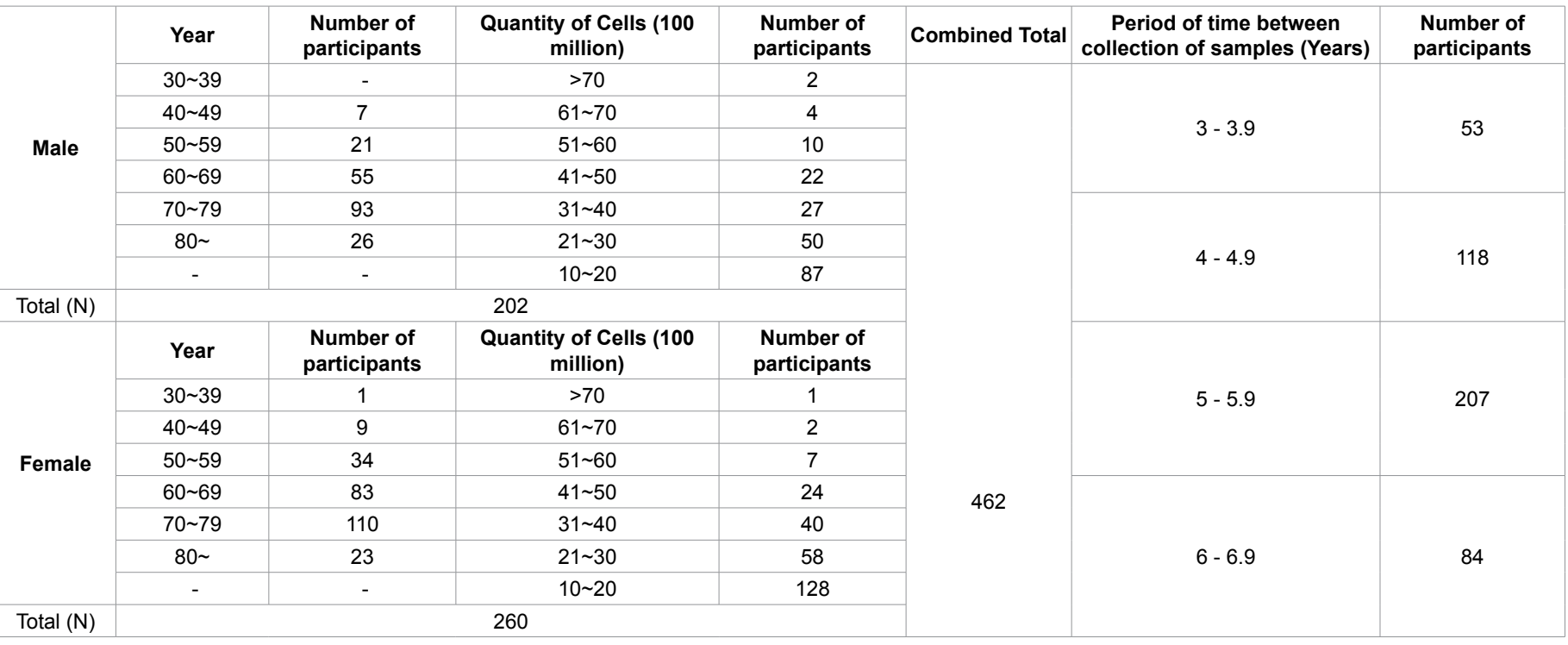

Table 3: The number of participants according to age, number of cells administered and period of time between the sample collections.

Diagnostics. Before the administration of stem cells, the serum samples (six years ago) were completely thawed at room temperature, vortexed, centrifuged, and examined. The fresh serum was immediately examined after the administration of stem cells.

\section{Statistical analysis}

In the case of continuous variables, the levels were presented as the mean \pm SD of the descriptive statistics (mean and standard deviation) regarding the changes before and after treatment for each tumor biomarker. Wilcoxon Signed Rank Test was used to verify any difference in the measured levels before and after treatment. Regarding safety assessment, McNemar's test was conducted to classify the normal and risk levels based on the risk level for each tumor biomarker. All statistical analyses were carried out using SAS V9.4. The two-sided test 
was performed at a 5\% significance level to identify differences before and after treatment.

\section{Results}

\section{Change in total numerical levels of tumor biomarkers before and after the intravenous administration of autologous adipose-derived stem cells}

The analysis of the mean levels of the diagnostic tumor biomarkers before and after the intravenous administration of cultured stem cells based on the tumor biomarker reference values and risk levels showed that all levels were within the normal reference range (Table 1 and Figure 1). The tumor biomarker levels did not exhibit any statistically significant difference between before and after intravenous administrations (Figure 2).

The distribution of tumor biomarkers for each group was analyzed according to their age and there was no change in tumor biomarkers except CEA and T-PSA. The participants' risk levels before and after administration decreased in CEA and increased in T-PSA by one person respectively (Table 2 ).

The analysis of the mean T-PSA tumor biomarker levels for participants who were administered cultured autologous adiposederived stem cells indicated that all the levels were within the safety range based on the T-PSA reference values and risk levels before and after administration (Table 1 and Figure 1).

\section{Change in each numerical level of tumor biomarkers before and after the intravenous administration of autologous adipose-derived stem cells}

The authors individually analyzed subjects whose levels were out of the reference value range or those whose levels had not initially been within the reference value range but then came within the reference value range (Tables 1 and 2). The analysis did not show any relationship between tumor biomarker levels and the number of stem cells administered or the elapsed time of blood samples taken.

In the case of CA72-4, the tumor biomarker levels of two subjects who had been at risk levels were within the reference value range after the administration of stem cells (S Table 2). In the case of T-PSA, the value of one subject whose values had been within the reference range deviated from the reference range after administration. In the case CEA, the tumor biomarker levels of one subject who had been at risk levels came within the normal range after the administration of stem cells (Figure 2). Except for these three cases, the analysis showed that there was no change in subjects whose tumor biomarker levels were at risk levels or their levels were changed but still remained within the risk value range before and after administration (Figure 2, S Tables 1 and 2).

In addition, the tumor biomarker AFP level was significantly reduced from $106.72 \mathrm{ng} / \mathrm{ml}$ to $6.32 \mathrm{ng} / \mathrm{ml}$ (Table 2). A 57 -year-old male who had chronic hepatitis $\mathrm{C}$, liver cirrhosis, and colon polyps was administered 2.85 billion cells. In the group that was administered 5.1-6.0 billion cells, some AFP levels slightly deviated from the normal range. After administration, the AFP levels were still not within the normal range but had decreased (Tables 1 and 2, Figure 2).

There was one subject (a 64-year-old male) whose T-PSA level was increased from $4.1 \mathrm{ng} / \mathrm{ml}$ to $11.7 \mathrm{ng} / \mathrm{ml}$ out of 202 subjects. Even before stem cell administration, the T-PSA level had been in the gray area, but it entered the risk range for prostate cancer after administration. However, the F/T PSA levels were within the risk range both before and after administration (Table 2).

\section{Discussion}

In this study, we did experiments using the blood of humans who had been intravenously administered one billion or more cultured autologous adipose-derived stem cells multiple times. Blood sample collection intervals ranged from three to six years, and at least three years had passed since the subjects were the first intravenously administered autologous adipose-derived stem cells.

Eight tumor biomarkers in total were measured in this study. Among them, AFP, CEA, CA19-9, and CA72-4 were used for both males and females. However, T-PSA and F/T PSA were only examined in males, and CA15-3 and CA125 were only examined in females. Reference values, reference intervals, and normal values have been used as standard values to interpret the results of tumor biomarker diagnostic tests. The term 'reference value' has been used relatively in frequent as a comparative criterion for determining whether a measured test result is obtained from a healthy person. The reference values are set based on the results of blood tests which were conducted on hundreds of healthy subjects. Most of the reference values used in this study were relatively lower than the normal values used in many papers and hospitals around the world. Therefore, it is possible to predict that a person who has a value outside the reference interval of this study is in a safe condition when using normal values.

The AFP is a type of serum protein that is originally present in a fetus during early pregnancy [13]. It is not detected in healthy adult blood, but it is used as a tumor marker for liver cancer, as its level is increased in $95 \%$ of patients with primary hepatic carcinoma. The AFP level is also elevated in fulminant hepatic failure and liver cirrhosis. Therefore, the analysis of the AFP level is useful for early detection, diagnosis, and follow-up of liver diseases including liver cancer. According to the EIA method, the normal value is $20 \mathrm{ng} / \mathrm{ml}$ [14]. AFP levels are elevated in $80-90 \%$ of patients with liver cancer, and a level $400 \mathrm{ng} / \mathrm{ml}$ or greater suggests a $95 \%$ of possibility of liver cancer [15] However, this level may be normal in small-sized liver cancer and may be increased to some extent in chronic hepatitis and cirrhosis. It is also a fetal protein that increases during pregnancy. Furthermore, it increases in germ cell tumors in the ovaries and testes. The normal range for AFP level is $0-20 \mathrm{ng} / \mathrm{ml}$, and a level greater than $400 \mathrm{ng} / \mathrm{ml}$ is very close to liver cancer [16].

The analysis of the group that was intravenously administered cultured autologous adipose-derived stem cells showed no change in the values for the subjects that were not within the risk range for liver tumor biomarkers between before and after administration (Table 2). In one case, the AFP level (a marker for hepatocellular carcinoma) was significantly decreased from $106.72 \mathrm{ng} / \mathrm{ml}$ to $6.32 \mathrm{ng} / \mathrm{ml}$ (Table 2). This case involved a 57 -year-old male who was administered 2.85 billion cells and had chronic hepatitis $\mathrm{C}$, liver cirrhosis, and colon polyps. This numerical result demonstrated that he had deviated from the high-risk group for liver cancer.

In addition, some AFP levels in the group that was administered 5.1-6.0 billion cells were slightly outside the normal range. Those were not within the normal range but had slightly decreased after administration. This result suggests that repeated administrations of 7 billion stem cells did not establish an environment for cancer formation (Tables 1 and 2, Figure 2). In contrast, there was one case in which the level in the high-risk group was lowered to the normal level.

Regarding that a normal range of AFP (a hepatocellular carcinoma marker) is $20 \mathrm{ng} / \mathrm{ml}$, the values that had been within the normal range 
A. AFP(reference< $7.0 \mathrm{ng} / \mathrm{ml}) /($ ris $\mathrm{k}>400 \mathrm{ng} / \mathrm{ml})$

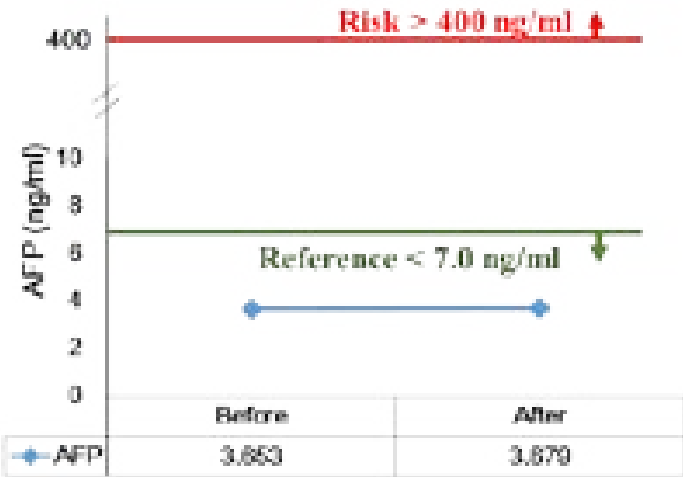

C. CA19-9(Reference $<39 \mathrm{U} / \mathrm{ml})($ Risk $>500 \mathrm{U} / \mathrm{ml})$

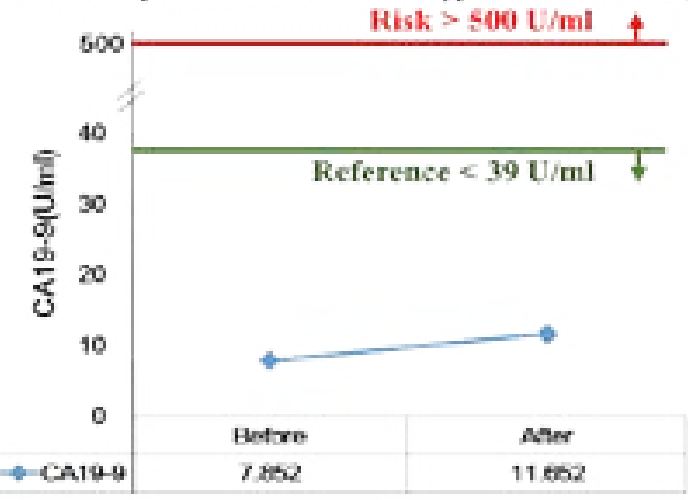

E. T-PSA(Reference<4.0 $\mathrm{ng} / \mathrm{ml}),(R i s k>10 \mathrm{ng} / \mathrm{ml})$

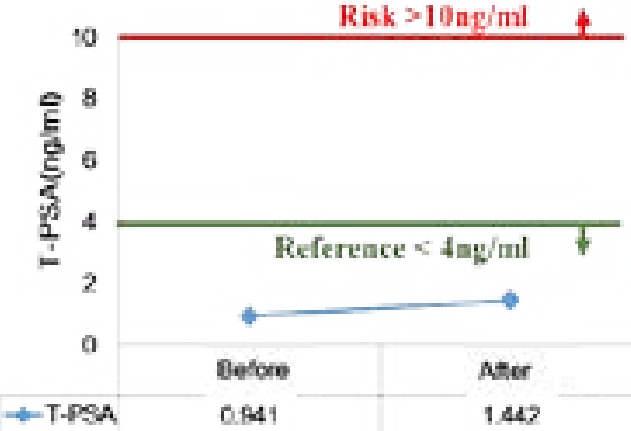

G. CA15-3(Reference $<26.4 \mathrm{U} / \mathrm{ml}) /(\mathrm{Risk}>30 \mathrm{U} / \mathrm{ml})$

40
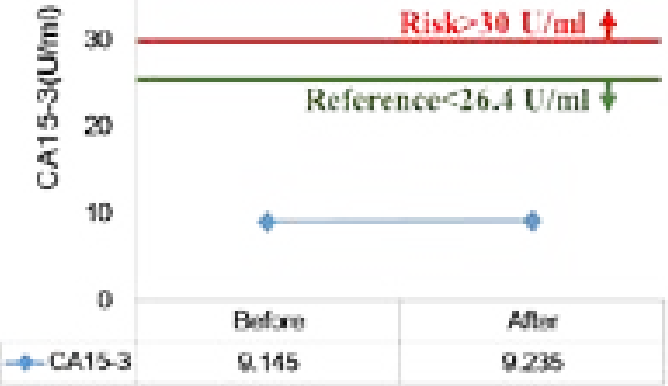

B. CEA(Reference $<4.7 \mathrm{ng} / \mathrm{ml})($ Risk $>10 \mathrm{ng} / \mathrm{ml})$

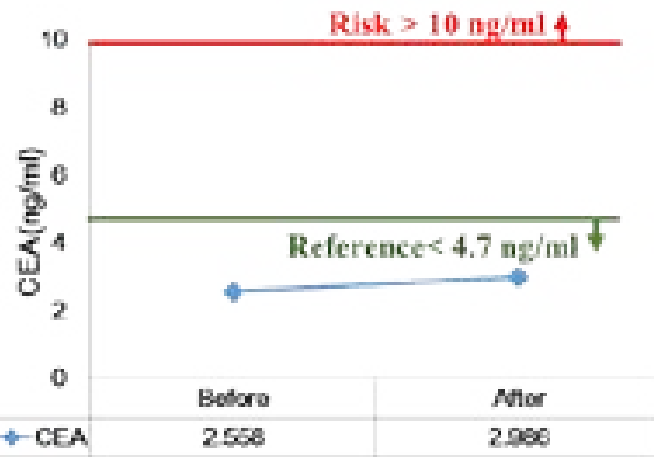

D. CA72-4(Reference $6.9 \mathrm{U} / \mathrm{mI})($ Ris $k>100 \mathrm{U} / \mathrm{ml})$

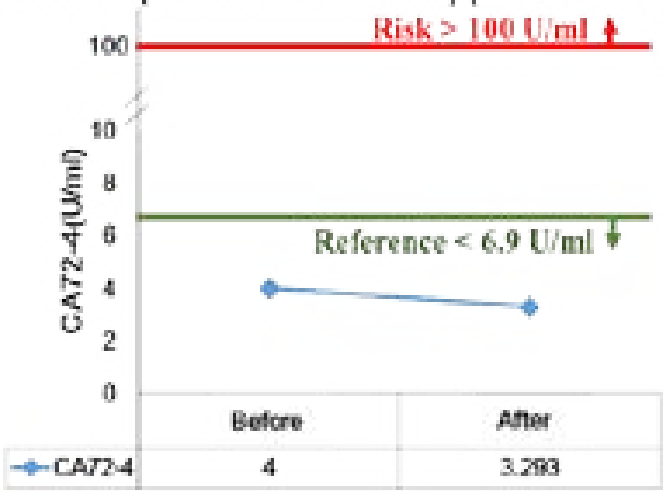

F. F/T-PSA(Reference $>23 \%) /($ Ris $k<10 \%$ )

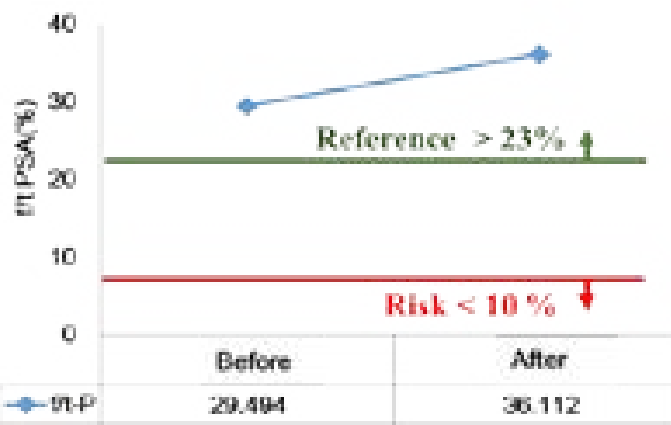

H. CA125(Reference<35U/mI)/(Risk $>60 \mathrm{U} / \mathrm{ml})$

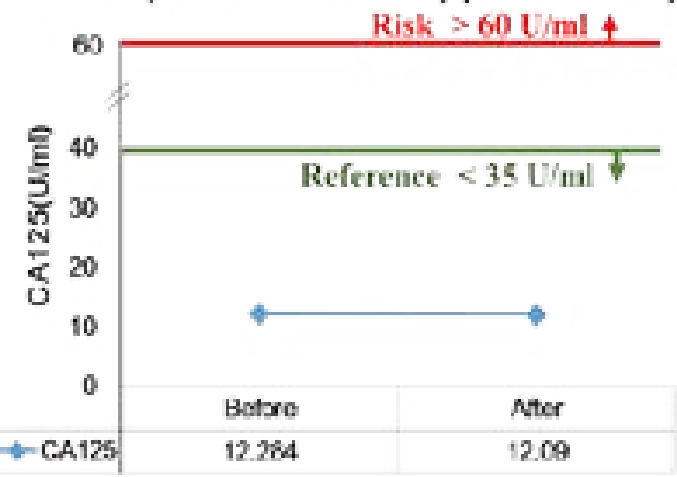

Figure 1: The mean level of each tumor biomarker before and after the IV. 


\section{A. $\operatorname{AFP}(>400 \mathrm{ng} / \mathrm{ml})$}

After

\begin{tabular}{cc|c|c|}
\multicolumn{1}{c}{} & \multicolumn{1}{c}{ Normal } & \multicolumn{1}{c}{ Risk } \\
\cline { 3 - 4 } Before & Normal & $\begin{array}{c}462 \\
(100 \%)\end{array}$ & $\begin{array}{c}0 \\
(0 \%)\end{array}$ \\
\cline { 3 - 4 } & & 0 & 0 \\
& Risk & $(0 \%)$ & $(0 \%)$ \\
\cline { 3 - 4 } & & &
\end{tabular}

C. CA19-9 $(>500 \mathrm{U} / \mathrm{ml})$

After

\begin{tabular}{cc|c|c|}
\multicolumn{1}{c}{} & \multicolumn{1}{c}{ Normal } & \multicolumn{1}{c}{ Risk } \\
\cline { 3 - 4 } Before & Normal & $\begin{array}{c}462 \\
(100 \%)\end{array}$ & 0 \\
& & $(0 \%)$ \\
\cline { 3 - 4 } & Risk & 0 & 0 \\
$(0 \%)$ & $(0 \%)$ \\
\hline
\end{tabular}

E. T-PSA(> $10.0 \mathrm{ng} / \mathrm{ml})$

After

\begin{tabular}{cc|c|c|}
\multicolumn{1}{c}{} & \multicolumn{1}{c}{ Normal } & \multicolumn{1}{c}{ Risk } \\
\cline { 3 - 4 } Before & Normal & 200 & 1 \\
$(99.01 \%)$ & $(0.50 \%)$ \\
\cline { 3 - 4 } & & 0 & 1 \\
& Risk & $(0 \%)$ & $(0.50 \%)$ \\
\cline { 3 - 4 } & & &
\end{tabular}

G. CA15-3(>30 U/ml)

After

\begin{tabular}{cc|c|c|}
\multicolumn{1}{c|}{} & \multicolumn{1}{c}{ Normal } & \multicolumn{1}{c}{ Risk } \\
\cline { 3 - 4 } Before & Normal & $\begin{array}{c}260 \\
(100 \%)\end{array}$ & $\begin{array}{c}0 \\
(0 \%)\end{array}$ \\
\cline { 3 - 4 } & & 0 & 0 \\
& Risk & $(0 \%)$ \\
\cline { 3 - 4 } & & & $0 \%)$
\end{tabular}

B. $\mathrm{CEA}(>10 \mathrm{ng} / \mathrm{ml})$

After

Normal Risk

\begin{tabular}{|c|c|c|c|}
\hline \multirow{2}{*}{ Before } & Normal & $\begin{array}{c}459 \\
(99.35 \%)\end{array}$ & $\begin{array}{c}0 \\
(0 \%)\end{array}$ \\
\hline & Risk & $\begin{array}{c}1 \\
(0.22 \%)\end{array}$ & $\begin{array}{c}2 \\
(0.43 \%)\end{array}$ \\
\hline
\end{tabular}

D. $\operatorname{CA} 72-4(>100 \mathrm{U} / \mathrm{ml})$

After

Normal Risk

Normal

Before

\begin{tabular}{|c|c|}
\hline $\begin{array}{c}460 \\
(99.57 \%)\end{array}$ & $\begin{array}{c}0 \\
(0 \%)\end{array}$ \\
\hline 2 & 0 \\
$(0.43 \%)$ & $(0 \%)$ \\
\hline
\end{tabular}

F. F/T-PSA $(<10 \%)$

After

\begin{tabular}{cc|c|c|}
\multicolumn{1}{c}{} & \multicolumn{1}{c}{ Normal } & \multicolumn{1}{c}{ Risk } \\
\cline { 3 - 4 } Before & Normal & $\begin{array}{c}200 \\
(99.01 \%)\end{array}$ & $\begin{array}{c}0 \\
(0 \%)\end{array}$ \\
\cline { 3 - 4 } & & 0 & 2 \\
& Risk & $(1.00 \%)$ \\
\cline { 3 - 4 } & & & \\
\cline { 3 - 4 } & & &
\end{tabular}

H. $\mathrm{CA125}(>60 \mathrm{U} / \mathrm{ml})$

After

Normal Risk

\begin{tabular}{|c|c|c|c|}
\hline & Normal & $\begin{array}{c}258 \\
(99.23 \%)\end{array}$ & $\begin{array}{c}1 \\
(0.38 \%)\end{array}$ \\
\hline efore & Risk & $\begin{array}{c}1 \\
(0.38 \%)\end{array}$ & $\begin{array}{c}0 \\
(0 \%)\end{array}$ \\
\hline
\end{tabular}

Figure 2: Safety assessment of the intravenous administration of cultured stem cells in terms of tumorigenicity. 
before stem cell administration deviated from the normal range after administration. Rather, there was a slight decrease from 0.43 to $0.23 \%$; these results indicate that there is no correlation between stem cell administration and liver cancer formation.

The CEA is usually present only in embryos and fetuses so its level is extremely low in adults; however, it is elevated in tumor formation. CEA was first identified in colorectal cancer. It is observed in $20-40 \%$ of tumors localized to the wall of large intestine, while it is observed in $80-95 \%$ of metastatic tumors. However, CEA biomarker is not restricted to colorectal cancer (70\%) but can be observed in pancreatic (60-90\%), stomach (40-60\%), lung (60-75\%), breast (20-50\%), uterine (45\%), and ovarian (25\%) cancer, thus caution should be taken when interpreting results. The level of this substance is less than $5 \mathrm{ng} / \mathrm{ml}$ in normal subjects; $5-10 \mathrm{ng} / \mathrm{ml}$ means that they are within the borderline, and $10 \mathrm{ng} / \mathrm{ml}$ or greater means that the likelihood of cancer formation has significantly increased [17]. This level has a low specificity for colorectal cancer, thus a high level of CEA does not necessarily indicate colorectal cancer. Eventually, this level does not play a significant role in the diagnosis of colorectal cancer. However, it has an important role in the treatment of colorectal cancer. CEA levels are relatively varied in the normal range according to smoking, gender, and age, which make it difficult to accurately determine the level. However, the normal range is generally $5-10 \mathrm{ng} / \mathrm{ml}$ and a finding of $10 \mathrm{mg} / \mathrm{ml}$ or greater presents an abnormality and would require further investigation [18]. According to the results of measuring the group that was intravenously administered cultured autologous adipose-derived stem cells, who had a CEA level deceased from $0.64 \%$ before administration to $0.43 \%$ after administration (Table 2). This result confirms that stem cell administration is not associated with colorectal cancer formation. We discovered that the CEA level of 69-year-old man decreased from a level within the risk range to within the normal range after administration of a high amount of stem cells (about 7.25 billion cells) (Table 1). This case demonstrates that there is no relationship between the number of stem cells administered and the number of stem cells and cancer formation.

The CA19-9 is produced in the epithelial cells of the human pancreas, gallbladder, stomach, and large intestine. It is an antibody that binds to a tumor marker, Sialyl-Lewis-A, which is produced in gastrointestinal tract tumor cells, especially tumor cells originated from the pancreas [18]. The produced CA19-9 is secreted into serum and is frequently used as a tumor biomarker for several gastrointestinal cancers including pancreatic and colorectal cancer [19]. It is particularly sensitive to pancreatic cancer, and the CA19-9 concentration in the serum is significantly decreased during the treatment of pancreatic cancer. However, the level may increase again due to the recurrence of lesions. Thus, it can be a useful marker for recurrence [20].

In terms of the CA19-9 level, $39 \mathrm{U} / \mathrm{ml}$ is set as a clinical diagnosis criterion in most cases. However, the positive predictive value of this method is very low $(0.9 \%)$ for screening purposes. CA19-9 levels have been reported to increase in both pancreatic cancer and malignant tumors such as lung, colorectal, stomach, liver, and ovarian cancer. They also increase in benign diseases including hyperthyroidism and hypothyroidism, thyroid nodule, diabetes mellitus, ovarian cystic tumor, endometritis, cervicitis, endometrial cancer, bronchiectasis, pulmonary tuberculosis, and mycobacterial infection [21]; $50 \%$ of patients with malignant tumors showed $500 \mathrm{U} / \mathrm{ml}$ or greater levels of CA19-9, and 1,000 U/ml or higher levels were observed in definite cancer progression [22]. Based on these results, $500 \mathrm{U} / \mathrm{ml}$ of CA19-9 should be used as a criterion for the predictive diagnostic risk level of cancer. Moreover, other markers, environmental factors, and subjects' pathological findings should be followed up.
Based on the CA19-9 reference and risk vales, the CA19-9 levels of the subjects who were administered cultured adipose-derived stem cells were all within the safe range before and after administration (Table 1 and Figure 1). Statistical analysis showed that there was no subject who had risk levels ( $0 \%$ ) before and after administration (Figure 2), thereby indicating that stem cell administration was not related to pancreatic cancer.

The CA72-4is a glycoprotein similar to mucus that has a high molecular weight and was first discovered by Colcher in 1981 [23]. This glycoprotein is detectable in the body fluids of cancer patients and was used as a marker for the diagnosis of malignant tumors in the gastrointestinal tract $[24,25]$. It is produced in both normal tissues and tumors in the digestive tract and is frequently used as a marker for various malignant diseases including those of the colon, stomach, and pancreas. It is particularly sensitive to stomach and ovarian cancer [26]. CA72-4 marker is used as a predictor of the postoperative surgical recurrence of stomach cancer. Neoplastic malignant tumors in stomach cancer have been currently reported as being diagnosed from serum and peritoneal lavage fluid. In terms of CA72-4 level, $6.9 \mathrm{U} / \mathrm{ml}$ is currently set as a criterion for clinical diagnosis. However, this level is increased by various diseases such as gastrointestinal disorders, gastric ulcers, and intestinal epithelium. It has been reported that when setting $100 \mathrm{U} / \mathrm{ml}$ as the risk level, the sensitivity is increased to $79 \%$ and the specificity is increased to $89 \%$ [27].

Based on the previous studies, we compared the CA72-4 levels in the serum of patients before and after the administration of cells. Patients in the risk range (greater than $300 \mathrm{U} / \mathrm{ml}$ ) had the following levels after administration: $1.7 \mathrm{U} / \mathrm{ml}$ and $6.8 \mathrm{U} / \mathrm{ml}$. Thus, we confirmed that the levels in the two patients within the risk range had reduced to within the reference value range (Table 2 and Figure 2). Therefore, we determined that the CA72-4 levels were maintained within a safe range regardless of stem cell administration, thereby suggesting no relationship between stem cell administration and stomach cancer formation.

The PSA is produced in the prostate epithelium and secreted into the blood. It is increased in the blood when cell destruction occurs. Therefore, it has been used for the early diagnosis of prostate cancer. Since Wang et al. [28] introduced a PSA purification method from prostate tissue in 1979, it has become the most useful test for early diagnosis due to its positive predictive value [29], high reproducibility, affordability and simplicity. However, its results are not satisfactory to sensitivity and specificity, leading to continuous attempts to increase these values [30].

One of the 202 subjects had a T-PSA level that increased from 4.1 $\mathrm{ng} / \mathrm{ml}$ to $11.7 \mathrm{ng} / \mathrm{ml}$. The subject was a 64 -year-old male whose T-PSA level belonged in the gray zone even before stem cell administration. The T-PSA level changed to the prostate cancer risk range after administration. However, he already had prostatic symptoms and been on medication before the administration. Furthermore, the F/T PSA levels were within the risk range before and after administration (Table 2). All of the tumor biomarker levels except T-PSA were within the reference range. This result may demonstrate that stem cell administration did not affect prostate cancer.

The T-PSA levels are very useful for screening patients who need prostate biopsy in the early screening for prostate cancer; however, there is limitation in distinguishing patients who do not have a high risk of prostate cancer [31]. Therefore, there have been attempts to develop, quantify, and apply other available markers such as prostate specific antigen density (PSAD), prostate specific antigen velocity (PSAV), , and 
F/T PSA ratios in patients. A prostate biopsy is required for the definite diagnosis of prostate cancer, and the most significant and fundamental test for determining whether to perform the biopsy is measuring serum PSA level [32]. The possibility of prostate cancer is relatively high when the serum PSA level is $10 \mathrm{ng} / \mathrm{ml}$ or higher. Therefore, in this case, a prostate biopsy should be conducted $[33,34]$. However, when serum PSA levels are $4-10 \mathrm{ng} / \mathrm{ml}$, only $25 \%$ of such cases are diagnosed as prostate cancer [35]. The specificity for PSA is decreased and an unnecessary biopsy can be performed. Many researchers have suggested improving the specificity and sensitivity of PSA via modified tests such as the rate of change of PSA, density of PSA, density of PSA according to the prostate transition zone volume, age-specific PSA, the ratio of free PSA, and molecular type of PSA [36-39]. Several previous studies have reported that the rate of free PSA is lower in patients with prostate cancer than in patients with benign prostatic hyperplasia [40,41]. This result means that the normal PSA range is $4-10 \mathrm{ng} / \mathrm{ml}$ and measuring free PSA is important for patients without any unique findings in terms of digital rectal examination. Therefore, we used free/total-prostate specific antigen (F/T-PSA) for tumor biomarker diagnosis.

According to the results, the rate of the subjects with F/T PSA ratio within the risk range $(0.49 \%)$ did not change between before and after the administration of stem cells (Table 2). An increase in F/T-PSA means a lower possibility of cancer. Our results showed that 158 out of 202 subjects $(78 \%)$ had increased F/T-PSA ratios after administration. Moreover, there were subjects whose $\mathrm{F} / \mathrm{T}$ ratios had increased 5.8 times and 7.15 times after the administration of stem cells. We also examined the F/T-PSA ratios for the group of subjects that had 4-10 $\mathrm{ng} / \mathrm{ml}$ T-PSA levels [42]; none of their F/T-PSA ratios were within the risk range. There was no change in the distribution of subjects with the risk range of the F/T-PSA ratio, but rather the levels were maintained at a stable condition or had entered the normal range after stem cell administration (Table 2). This suggests that stem cell administration was not associated with cancer formation but rather may have helped to reduce the risk of cancer.

The CA15-3 is a protein produced in normal mammary epithelial tissues and is typically used as a breast tumor biomarker. It is also positive in ovarian cancer (40\%), uterine cancer (20\%), lung cancer (20\%), liver cancer, liver cirrhosis, hepatitis, and benign breast disease. However, CA15-3 is not sufficiently sensitive or specific to be used as a means of cancer screening. Therefore, it is mainly used to monitor the response to breast cancer treatment and observe recurrence. Its level is elevated in over $80 \%$ of metastatic breast cancer; the level is increased more sensitively in distant metastases than in local recurrence and its level is $30 \mathrm{U} / \mathrm{ml}$ or less in normal subjects. If the level is above $30 \mathrm{U} /$ $\mathrm{ml}$, the progression of breast cancer is severe, and the tumor burden is greater than normal subjects [43]. A previous study also reported that umbilical cord stem cells attenuated the growth of breast cancer cells in animal models [44].

According to the results of measuring the group that was intravenously administered cultured autologous adipose-derived stem cells, the rate of subjects with CA15-3 levels within the risk range (0\%) did not change before or after the administration of stem cells (Table 2). The results of each subject also showed no case in which the levels were not within the reference values (S Table 1). These results determine that stem cell administration was not related to breast cancer formation.

A polymeric glycoprotein, CA 125 is present in the mesoderm of fetuses and adults, Mullerian duct-derived organs, adult fallopian tubes, endometrium, peritoneum, and pleura. Production of CA 125 is increased in tumors in these organs or tissues or inflammatory diseases, and is especially high in serous ovarian cancer. It is very useful for determining the prognosis and therapeutic effect of endometrial and ovarian cancer. However, its level is also elevated in benign diseases such as endometriosis, benign ovarian cysts, and pelvic inflammation, and even in menstruation and the first trimester of pregnancy, thereby demonstrating its low value as a screening method [45]. In ovarian cancer stage 1 , only $50 \%$ of ovarian cancers showed a positive result. During progression through stages 2,3 , and 4 , the positive rate increased to $80 \%$. Therefore, using this test alone has limitations in the early diagnosis of cancer. According to the European Group on Tumor Marker and the National Academy of Clinical Biochemistry, there is lack of evidence of using CA 125 for screening or diagnosing ovarian cancer. However it is useful for determining illness and prognosis, and monitoring recurrence and treatment effects. The reference value of CA 125 is generally in the range $0-35 \mathrm{U} / \mathrm{ml}$, but its specificity is low. Therefore, we determined $35-65 \mathrm{U} / \mathrm{ml}$ as the normal range, thereby increasing the test's sensitivity. We used more than $60 \mathrm{U} / \mathrm{ml}$ as the risk level [46]. The CA-125 level was increased in ovarian cancer, but it may also be elevated in benign diseases including myoma uteri, adenomyosis, pelvic inflammation and endometriosis, pregnancy, and endometrioma (benign ovarian tumor) or other ovarian cysts. Furthermore, the level may increase in endometrium, fallopian tubes, lungs, breast, and cancer derived from the digestive system [47]. According to the results of measuring the group that was intravenously administered cultured autologous adipose-derived stem cells, the rate of subjects with CA125 levels within the risk range $(0.38 \%)$ did not change before or after the administration of stem cells (Table 2).

Thus, our results, when measuring the tumor biomarker levels, confirm that stem cells were not associated with tumor formation. In addition, the authors individually examined the subjects who had tumor biomarker levels outside the reference range and whose biomarker levels had been outside the reference range but entered the reference range after administration (Tables 1 and 2). The result demonstrated that there was no relationship between tumor biomarker levels, the number of stem cells administered, and the elapsed time from when blood samples were taken.

\section{Conclusion}

Based on this result, we expect that the multiple administrations of cells are not related to cancer. In addition, there was no statistically significant difference in the tumor biomarker levels before and after the intravenous administration of autologous adipose-derived stem cells (Figure 2). This result supports that stem cell administration was not associated with cancer.

In conclusion, for the first time in the world, we confirm that there is no possibility of cancer occurrence from multiple intravenous administrations of cultured autologous adipose-derived stem cells.

\section{References}

1. Koh KS, Oh TS, Kim H, Chung IW, Lee KW, et al. (2012) Clinical application of human adipose tissue-derived mesenchymal stem cells in progressive hemifacial atrophy (Parry-Romberg disease) with micro fat grafting techniques using 3-dimensional computed tomography and 3-dimensional camera. Ann Plast Surg 69: 331-337

2. Lee HC, An SG, Lee HW, Park JS, Cha KS, et al. (2012) Safety and effect of adipose tissue-derived stem cell implantation in patients with critical limb ischemia: A pilot study. Circ J 76: 1750-1760.

3. Jo CH, Lee YG, Shin WH, Kim H, Chai JW, et al. (2014) Intra-articular injection of mesenchymal stem cells for the treatment of osteoarthritis of the knee: $A$ proof-of-concept clinical trial. Stem Cells 32: 1254-1266.

4. Ra JC, Shin IS, Kim SH, Kang SK, Kang BC, et al. (2011) Safety of intravenous 
infusion of human adipose tissue-derived mesenchymal stem cells in animals and humans. Stem Cells Dev 20: 1297-1308.

5. Ra JC, Kang SK, Shin IS, Park HG, Joo SA, et al. (2011) Stem cell treatment for patients with autoimmune disease by systemic infusion of culture-expanded autologous adipose tissue derived mesenchymal stem cells. J Transl Med 9: 181.

6. Kim S, Chang KA, Kim JA, Park HG, Ra JC, et al. (2012) The preventive and therapeutic effects of intravenous human adipose-derived stem cells in Alzheimer's disease mice. PLoS One 7: e45757.

7. Park D, Yang G, Bae DK, Lee SH, Yang YH, et al. (2013) Human adipose tissue-derived mesenchymal stem cells improve cognitive function and physical activity in ageing mice. J Neurosci Res 91: 660-670.

8. Chu Y, Tang H, Guo Y, Guo J, Huang B, et al. (2015) Adipose-derived mesenchymal stem cells promote cell proliferation and invasion of epithelial ovarian cancer. Exp Cell Res 337: 16-27.

9. Yu JM, Jun ES, Bae YC, Jung JS (2008) Mesenchymal stem cells derived from human adipose tissues favor tumor cell growth in vivo. Stem Cells Dev 17: 463-473.

10. Choi SA, Lee JY, Kwon SE, Wang KC, Phi JH, et al. (2015) Human adipose tissue-derived mesenchymal stem cells target brain tumor-initiating cells. PLoS One 10: e0129292.

11. Grisendi G, Bussolari R, Cafarelli L, Petak I, Rasini V, et al. (2010) Adiposederived mesenchymal stem cells as stable source of tumor necrosis factorrelated apoptosis-inducing ligand delivery for cancer therapy. Cancer Res 70 : 3718-3729.

12. Kucerova L, Altanerova V, Matuskova M, Tyciakova S, Altaner C (2007) Adipose tissue-derived human mesenchymal stem cells mediated prodrug cancer gene therapy. Cancer Res 67: 6304-6313.

13. Nahon JL (1987) The regulation of albumin and alpha-fetoprotein gene expression in mammals. Biochimie 69: 445-459.

14. Gadsden RH, Cate JC (1991) Serum alpha-fetoprotein: I. Evaluation of quantitative assays adapted to automated immunoassay systems. Ann Clin Lab Sci 21: 246-253.

15. Duffy MJ (2010) Use of biomarkers in screening for cancer. EJIFCC 21:1-12

16. Raphael SW, Yangde Z, Yuxiang C (2012) Hepatocellular carcinoma: Focus on different aspects of management. ISRN Oncol 2012: 1-12.

17. Higashiyama M, Kodama K, Higaki N, Takami K, Murata K, et al. (2003) Surgery for pulmonary metastases from colorectal cancer: the importance of prethoracotomy serum carcinoembryonic antigen as an indicator of prognosis. Jpn J Thorac Cardiovasc Surg 51: 289-296.

18. Perkins GL, Slater ED, Sanders GK, Prichard JG (2003) Serum tumor markers. Am Fam Physician 68:1075-1082

19. Youssef EMI, Ewieda GH, Ali HAA, Tawfik AM, El-Fatah WMEA, et al. (2013) Comparison between CEA, CA 19-9 and CA 72-4 in Patients with Colon Cancer. Int J of Tumor Therapy 2: 26-34.

20. Locker GY, Hamilton S, Harris J, Jessup JM, Kemeny N, et al. (2006) ASCO 2006 update of recommendations for the use of tumor markers in gastrointestinal cancer. J Clin Oncol 24: 5313-5327.

21. Kim JE, Lee KT, Lee JK, Paik SW, Rhee JC, et al. (2004) Clinical usefulness of carbohydrate antigen 19-9 as a screening test for pancreatic cancer in an asymptomatic population. J Gastroenterol Hepatol 19: 182-186.

22. Pavai S, Yap SF (2003) The clinical significance of elevated levels of serum CA 19-9. Med J Malaysia 58: 667-672.

23. Colcher D, Hand PH, Nuti M, Schlom J (1981) A spectrum of monoclonal antibodies reactive with human mammary tumor cells. Proc Nalt Acad Sci USA 78: 3199-3203.

24. Byrne DJ, Browning MC, Cuschieri A (1990) CA72-4: A new tumor marker for gastric cancer. Br J Surg 77: 1010-1013.

25. Guadagni F, Roselli M, Amato T, Cosimelli M, Mannella E, et al. (1991) Tumorassociated glycoprotein-72 serum levels complement carcinoembryonic antigen levels in monitoring patients with gastrointestinal carcinoma. A longitudinal study. Cancer 68: 2443-2450.

26. Goral V, Yesilbagdan H, Kaplan A, Sit D (2007) Evaluation of CA72-4 as a new tumor marker in patients with gastric cancer. Hepatogastroenterology 54 $1272-1275$.

27. Keller J, Sklan ER, Refael M, Andresen V, Herman YL, et al. (2012) CA72-4 may contribute to real-time reconnaissance of gastric cancer. F1000Research $1: 33$

28. Wang MC, Valenzuela LA, Murphy GP, Chu TM (1979) Purification of a human prostate specific antigen. Invest urol 17: 159-163.

29. Catalona WJ, Richie JP, Ahmann FR, Hudson MA, Scardino PT, et al. (1994) Comparison of digital rectal examination and serum prostate specific antigen in the early detection of prostate cancer: Results of a multicenter clinical trial of 6,630 men. J Urol 151: 1283-1290.

30. Lee MK, Park YK, Park AJ (2001) Reevaluation of the reference range of prostatespecific antigen in Korean men. J Clin Pathol Qual Control 23: 221-226.

31. Schroder FH, Van der Cruijsen-Koeter I, De Koning HJ, Vis AN, Hoedemaeker RF, et al. (2000) Prostate cancer detection at low prostate specific antigen. $J$ Urol 163: 806-812.

32. Oesterling JE (1991) Prostate specific antigen: A critical assessment of the most useful tumor marker for adenocarcinoma of the prostate. J Urol 145: 907-923.

33. Dalva I, Akan H, Yildiz O, Telli C, Bingol N (1999) The clinical value of the ratio of free prostate specific antigen to total prostate specific antigen. Int Urol Nephrol 31: 675-680.

34. Sturgeon CM, Duffy MJ, Stenman UH, Lilja H, Brünner N, et al. (2008) National Academy of Clinical Biochemistry laboratory medicine practice guidelines for use of tumor markers in testicular, prostate, colorectal, breast, and ovarian cancers. Clin Chem 54: e11-79.

35. Labrie F, Dupont A, Suburu R, Cusan L, Tremblay M, et al. (1992) Serum prostate specific antigen as prescreening test for prostate cancer. J Urol 147 846-851.

36. Benson MC, Whang IS, Olsson CA, McMahon DJ, Cooner WH (1992) The use of prostate specific antigen density to enhance the predictive value of intermediate levels of serum prostate specific antigen. J Urol 147: 817-821.

37. Oesterling JE, Jacobsen SJ, Chute CG, Guess HA, Girman CJ, et al. (1993) Serum prostate specific antigen in a community-based population of healthy man. Establishment of age-specific reference ranges. JAMA 270: 860-864

38. Kalish J, Cooner WH, Graham SD Jr. (1994) Serum PSA adjusted for volume of transition zone (PSAT) is more accurate than PSA adjusted for total gland volume (PSAD) in detecting adenocarcinoma of the prostate. Urology 43: 601-606.

39. Catalona WJ, Smith DS, Wolfert RL, Wang TJ, Rittenhouse HG, et al. (1995) Evaluation of percentage of free serum prostate-specific antigen to improve specificity of prostate cancer screening. JAMA $274: 1214-1220$.

40. Stenman UH, Hakama M, Knekt P, Aromaa A, Teppo L, et al. (1994) Serum concentrations of prostate specific antigen and its complex with a1antichymotrypsin before diagnosis of prostatic cancer. Lancet 344: 1594-1598

41. Bialecki ES, Di Bisceglie AM (2005) Diagnosis of hepatocellular carcinoma HPB (Oxford) 7: 26-34.

42. Erol B, Gulpinar MT, Bozdogan G, Ozkanli S, Onem K, et al. (2014) The cutoff level of free/total prostate specific antigen ( $f / t$ PSA) ratios in the diagnosis of prostate cancer: A validation study on a Turkish patient population in different age categories. Kaohsiung J Med Sci 30: 545-550.

43. Park NK, Woo HD, Sohn DM, Kim SY, Lim CW, et al. (2008) The correlation of serum HER-2/neu and CA15-3 in patients with metastatic breast cancer. $J$ Breast Cancer 11: 18-24.

44. Ayuzawa R, Doi C, Rachakatla, RS, Pyle MM, Maurya DK, et al. (2009) Naive human umbilical cord matrix derived stem cells significantly attenuate growth of human breast cancer cells in vitro and in vivo. Cancer Lett 280: 31-37.

45. Kim CR, Ku CH, Jeon IS, Son DW, Lee JS (2013) The clinico-pathologic features and significance of preoperative CA 125 in patients who had an operation for ovarian tumors. J Korean Soc Menopause 19: 26-35.

46. Gupta D, Lis CG (2009) Role of CA125 in predicting ovarian cancer survival - A review of the epidemiological literature. J Ovarian Res 2: 13.

47. Podczaski E, Whitney C, Manetta A, Larson JE, Kirk J, et al. (1989) Use of CA 125 to monitor patients with ovarian epithelial carcinomas. Gynecol Oncol 33 193-197. 